\title{
KONSEKUENSI YURIDIS PUTUSAN MAKAMAH KONSTITUSI \\ NO. 46/PUU-VIII/2010 TERHADAP KEDUDUKAN ANAK ASTRA \\ DALAM HUKUM ADAT BALI
}

Oleh :

I Gede Pasek Pramana ${ }^{1}$

\begin{abstract}
This research aims to analyze about the significance of the Constitutional Court Decision No.46/PUU-VIII/2010 the position of anak astra in Bali customary law. The research method used is a normative study by selecting the type of statue approach and the conceptual approach. Sources of legal materials that were examined in this study consisted of primary legal materials and secondary legal materials and techniques were analyzed with the description, systematic, evaluation and argumentation. Based on the perspective ( review) Constitutional Court Decision No. 46/PUU-VIII/2010, anak astra have a civil relationship with her biological father and his family along can be proved by science and technology and / or other evidence according to the law. The juridical consequences of the Constitutional Court Decision No. 46/PUU-VIII/2010 to the norms of Bali customary law about anak astra Bali is must conform to the directions of law in the Decision of the Constitutional Court.
\end{abstract}

Key word : Anak astra, Constitutional Court Decision No. 46/PUU-VIII/2010, Legal Position

\footnotetext{
${ }^{1}$ Mahasiswa Magister Ilmu Hukum Universitas Udayana, Denpasar, Bali. Alamat JL. Jl. Ratna No. 44 Denpasar, e-mail: pasek_mail@yahoo.com
} 


\section{PENDAHULUAN}

\section{a. Latar Belakang}

Anak mempunyai arti penting bagi suatu keluarga, karena : (1) anak adalah penerus suatu generasi ; (2) anak adalah harapan yang menjadi tujuan perkawinan ; (3) anak sebagai ahli waris dalam keluarga ; (4) anak sebagai harapan orang tua ketika orang tua sudah tidak mampu ; (5) dan dalam konteks adat Bali, anak dipercaya sebagai pihak yang dapat menghantarkan arwah leluhurnya menuju surga. ${ }^{2}$ Atas dasar tersebut, maka sangat wajar jika anak diberikan perlindungan oleh negara. Berdasarkan Undang-undang No. 1 Tahun 1974 tentang Perkawinan, dikenal dua golongan anak, yakni anak sah dan tidak sah. Menurut Pasal 42 Undang-undang tentang perkawinan, anak sah ialah anak yang dilahirkan dalam atau sebagai akibat perkawinan yang sah, sedangkan anak yang lahir dari perkawinan yang tidak sah digolongkan sebagai anak luar kawin.

Dalam kaitannya dengan anak luar kawin, hukum adat Bali juga mengenal status anak yang serupa yang dibedakan lagi dalam dua jenis, yaitu : ${ }^{4}$

\footnotetext{
${ }^{2}$ Ni Nyoman Sukerti, 2012, Hak Mewaris Perempuan Dalam Hukum Adat Bali Sebuah Studi Kritis, Udayana University Press, Denpasar, h. 9-10

${ }^{3}$ D. Y. Witanto, 2012, Hukum Keluarga Hak dan Kedudukan Anak Luar Kawin Pasca Keluarnya Putusan MK Tentang Uji Materiil UU Perkawinan, Prestasi Pustaka Publisher, Jakarta, h. 4

${ }^{4}$ ibid, h. 63
}

a. anak bebinjat adalah anak luar kawin yang sama sekali tidak diketahui siapa ayah biologisnya;

b. anak astra adalah anak luar kawin yang sudah diketahui siapa ayah biologisnya Berdasarkan Pasal 43 ayat (1) Undangundang tentang Perkawinan, hubungan keperdataan yang dimiliki oleh si anak luar kawin hanya dibatasi pada ibu dan keluarga ibunya saja. Dengan demikian, substansi Pasal 43 tersebut dapat ditafsirkan sebagai tindakan yang bersifat meniadakan hak-hak anak terhadap laki-laki yang menjadi bapak biologisnya. Ditambah lagi dengan pandangan masyarakat yang diskriminatif terhadap anak luar kawin akan menjadi beban kejiwaan bagi si anak, dan hal itu akan mempengarui keseimbangan mental spiritual si anak dalam pergaulan hidupnya.

Ketentuan di atas sangat bertolak belakang dengan prinsip perlindungan dan penghormatan konstitusional terhadap hak asasi manusia dalam suatu negara hukum. ${ }^{5}$ Pada tahun 2012, Makamah Konstitusi menetapkan sebuah Putusan tentang pengujian atas Undang-undang tentang Perkawinan terhadap Undang-Undang Dasar Negara Republik Indonesia Tahun 1945. Putusan yang dimaksud adalah Putusan Makamah Konstitusi No. 46/PUUVIII/2010. Salah satu point penting yang

\footnotetext{
${ }^{5}$ Jimly Ashiddiqie, 2010, Konstitusi dan Konstitusionlisme Indonesia, Sinar Grafika, Jakarta, h. 132
} 
tertuang di dalam amar putusan tersebut, menegaskan bahwa Pasal 43 ayat (1) Undang-Undang tentang Perkawinan adalah bertentangan dengan Undang-Undang Dasar dan tidak memiliki kekuatan hukum mengikat sepanjang dimaknai menghilangkan hubungan perdata dengan laki-laki yang ternyata dapat dibuktikan mempunyai hubungan darah sebagai ayahnya. Melalui Putusan Makamah Konstitusi tersebut, tercermin arah politik hukum Indonesia terhadap kedudukan anak luar kawin di dalam Undang-undang tentang perkawinan.

Bagaimana halnya jika Putusan Makamah Konstitusi No. 46/PUU-VIII/2010 dihadapkan dengan hukum adat Bali tentang anak astra? Sebagaimana diketahui, hukum adat Bali ini diakui keberadaannya secara konstitusional berdasarkan Pasal 18 B ayat (2) Undang-undang Dasar Negara Republik Indonesia Tahun 1945. Berdasarkan hukum adat Bali, anak astra hanya memiliki hubungan perdata dengan ibunya, meskipun diketahui siapa bapak biologisnya. Dengan demikian, timbul permasalahan hukum mengenai konsekuensi Putusan Makamah Konstitusi tersebut terhadap kedudukan anak astra dalam hukum adat Bali. Bertolak dari pemikiran tersebut, maka arti penting dari Putusan Makamah Konstitusi No. 46/PUUVIII/2010 terhadap kedudukan anak astra dalam hukum adat Bali menarik untuk dikaji.

\section{b. Rumusan Masalah}

1. Bagaimanakah kedudukan anak astra ditinjau dari Putusan Makamah Konstitusi No. 46/ PUU- VIII/2010?

2. Bagaimanakah konsekuensi yuridis Putusan Makamah No. 46/PUUVIII/2010 terhadap hukum adat Bali yang mengatur tentang anak astra?

\section{c. Tujuan Penelitian}

Tujuan umum dari penelitian kali ini adalah untuk mengetahui dan menganalisa tentang arti penting dari konsekuensi yuridis Putusan Makamah Konstitusi No. 46/PUUVIII/2010 terhadap kedudukan anak astra dalam perkembangan hukum adat Bali. Sedangkan yang menjadi tujuan khusus, antara lain :

1. Untuk mengetahui kedudukan anak astra ditinjau dari Putusan Makamah Konstitusi No. 46/PUU-VIII/2010

2. Untuk mengetahui konsekuensi yuridis Putusan Makamah No. 46/PUUVIII/2010 terhadap kedudukan hukum adat yang mengatur tentang anak astra.

\section{METODE PENELITIAN}

Penelitian ini merupakan penelitian hukum normatif, karena menyangkut taraf sinkronisasi antara dua sistem hukum, yaitu hukum tertulis dan hukum tidak tertulis 
(hukum adat) dalam kaitannya dengan pengaturan kedudukan anak luar kawin. Dalam hal ini akan diteliti sinkronisasi pengaturan anak luar kawin dalam Undangundang tentang Perkawinan pasca Putusan Mahkamah Konstitusi No. 46/PUUVIII/2010 dan hukum adat Bali. Sesuai dengan permasalahan yang dikaji, maka pendekatan yang digunakan dalam penelitian ini adalah pendekatan perundang-undangan dan pendekatan konseptual. Adapun bahan hukum yang dipergunakan di dalam penelitian ini, berupa bahan hukum primer yang terdiri dari beberapa jenis peraturan perundang-undangan dan bahan hukum sekunder, yang meliputi buku-buku ataupun literatur-literatur, jurnal-jurnal hukum, pendapat para sarjana dan yurisprudensi yang relevan dengan permasalahan yang diteliti.

\section{HASIL DAN PEMBAHASAN}

\section{a. Kedudukan Anak Astra Ditinjau Dari}

\section{Putusan Makamah Konstitusi}

\section{No. 46/PUU-VIII/2010}

Jimly Asshiddqie mengemukakan bahwa Indonesia adalah negara hukum. ${ }^{6}$ Di dalam negara hukum terkandung prinsipprinsip : (1) adanya pengakuan terhadap prinsip supremasi hukum dan konstitusi ; (2) dianutnya prinsip pemisahan dan pembatasan kekuasaan menurut sistem

\footnotetext{
${ }^{6}$ Jimly Ashiddiqie, op.cit, h. 57
}

konstitusional yang diatur dalam Undangundang Dasar ; (3) adanya Jaminan hak asasi manusia dalam Undang-undang Dasar ; (4) adanya prinsip peradilan yang bebas dan tidak memihak yang menjamin setiap warga negara dalam hukum, serta (5) menjamin keadilan bagi setiap orang termasuk terhadap penyalahgunaan wewenang oleh pihak yang berkuasa. Khususnya tentang jaminan hak asasi manusia, landasan konstitusional hak asasi manusia di Indonesia adalah TAP MPR No. XVII/MPR/998 dan Undang-undang Dasar Negara Republik Indonesia Tahun 1945 yang dituangkan di dalam Bab XA, dari Pasal 28A sampai dengan Pasal 28J. Dalam tataran undang-undang, perlindungan hak asasi manusia diatur dalam Undangundang No. 39 Tahun 1999 tentang Hak Asasi Manusia.

Anak juga manusia, dan karenanya menghormati hak asasi anak sama halnya menghormati hak asasi manusia. ${ }^{7}$ Secara yuridis hak-hak anak telah mempunyai landasan yang kuat. Undang-undang No. 39 Tahun 1999 tentang Hak asasi Manusia telah mencantumkan tentang hak anak. Di samping itu, pemerintah telah membentuk Undang-undang No. 23 Tahun 2002 tentang Perlindungan Anak sebagai landasan yuridis yang bersifat khusus. Dalam undang-undang

\footnotetext{
${ }^{7}$ Yusuf Hanfi, 2011, Kontroversi Perkawinan Anak di Bawah Umur Perspektif Fikih Islam, HAM Internasional, dan UU Nasional, CV. Mandar Maju, Bandung, h.28
} 
tersebut, salah satu prinsip penting yang dianut adalah prinsip nondiskriminasi.

Dalam kaitannya dengan keberadaan anak luar kawin, ketentuan Pasal 43 ayat (1) Undang-undang No. 1 Tahun 1974 pada dasarnya menimbulkan kerugian bagi anak yang lahir di luar perkawinan yang tidak sah, karena bersifat sangat diskriminatif terhadap kepentingan si anak. Intinya berdasarkan Pasal 43 ayat (1) Undang-undang tentang Perkawinan, bagi anak yang lahir diluar perkawinan yang sah, tidak dapat diakui hubungan anak dengan bapak kandung (bapak biologis)-nya. Oleh karenanya, tidak ada kewajiban dari bapak kandungnya untuk membiayai kebutuhan hidup dan memenuhi hak-hak keperdataan lain yang melekat pada anak. Tanpa memiliki kejelasan status ayah, umumnya anak sering mendapat perlakuan yang tidak adil dan pandangan negatif di tengah-tengah masyarakat. Deskripsi inilah yang menunjukan pembedaan terhadap anak karena didasarkan pada alasan status kelahirannya dan dapat dikategorikan sebagai tindakan yang diskriminatif. Oleh karenanya, Melalui Putusan Makamah Konstitusi No. 46/PUU-VIII/2010, ketentuan Pasal 43 ayat (1) Undang-undang tentang Perkawinan dianggap bersifat inkonstitusional. Di samping itu dengan pertimbangan kemajuan teknologi seperti adanya tes deoxyribo nucleic acid (DNA), maka memungkinkan dapat dibuktikan bahwa seorang anak itu merupakan anak dari laki-laki tertentu.

Meskipun latar belakang Putusan Makamah Konstitusi No. 46/PUU-VIII/2010 adalah menyangkut masalah yang timbul akibat perkawinan siri, namun jika dicermati kembali uraian pertimbangan Makamah Konstitusi, maka sebenarnnya maksud dari pertimbangan tersebut tidak hanya berlaku bagi anak luar kawin dalam pengertian hasil dari perkawinan siri, melainkan juga berlaku bagi seluruh anak luar kawin pada umumnya, termasuk anak zina dan anak sumbang. ${ }^{8}$ Hal ini dapat dilihat dari isi pertimbangan Putusan Mahkamah Kontitusi yang berkaitan dengan pokok persoalan yang diajukan oleh Pemohon judicial review, yakni :

Dengan demikian, terlepas dari soal prosedur/administrasi perkawinannya, anak yang dilahirkan harus mendapatkan perlindungan hukum. Jika tidak demikian, maka yang dirugikan adalah anak yang dilahirkan di luar perkawinan, padahal anak tersebut tidak berdosa karena kelahirannya di luar kehendaknya. Anak yang dilahirkan tanpa memiliki kejelasan status ayah seringkali mendapatkan perlakuan yang tidak adil dan stigma di tengah-tengah masyarakat. Hukum harus memberi perlindungan dan kepastian hukum yang adil terhadap status seorang anak yang dilahirkan dan hak-hak yang ada padanya, termasuk terhadap anak yang dilahirkan meskipun keabsahan perkawinannya masih dipersengketakan.

${ }^{8}$ D.Y. Witanto, op.cit, h. 252 
Dari seluruh uraian di atas, maka ruang lingkup maksud dan tujuan Putusan Makamah Kontitusi No. 46/PUU-VIII/2010 adalah berlaku bagi seluruh anak luar kawin, tidak terkecuali anak astra di Bali.

Dengan demikian, maka dapat diketahui kedudukan anak astra dalam Putusan Makamah Konstitusi. Terlepas dari soal keabsahan perkawinan orang tuanya, sebagai anak luar kawin, anak astra wajib memperoleh perlindungan dan kepastian hukum yang adil terhadap status dan hak-hak yang ada padanya. Oleh karenanya, menurut Putusan Makamah Kontitusi, anak astra berhak memiliki hubungan keperdataan dengan bapak biologisnya beserta keluarganya sepanjang dapat dibuktikan berdasarkan ilmu pengetahuan dan teknologi dan/atau alat bukti lain menurut hukum.

b. Konsekuensi Yuridis Putusan makamah Konstitusi No. 46/PUUVIII/2010 Terhadap Kedudukan

\section{Hukum Adat Bali Tentang Anak Astra}

Terdapat beragam sistem hukum yang dianut oleh negara-negara di dunia, ${ }^{9}$ yakni civil law system, common law system, costumary law system, muslim law system dan lain-lain. Meskipun dalam penjelasan Undang-undang Negara Republik Indonesia 1945 disebutkan bahwa negara berdasarkan rechstaat (civil law system), namun menurut

${ }^{9}$ Otong Rosadi, Andi Desmon, 2012, Studi Politik Hukum Suatu Optik Ilmu Hukum, Thafa Media,Yogyakarta, h. 21
Romli Atmasasmita dalam Otong Rosadi dan Andi Desmon karakteristik sistem hukum di Indonesia adalah belum terbentuk secara holistik dan komperhensif. ${ }^{10}$ Sebagai contoh, bangsa Indonesia mewarisi tradisi hukum Eropa Kontinental (civil law), sehingga kita cenderung menumpahkan begitu banyak perhatian pada kegiatan pembentukan hukum (undang-undang). ${ }^{11}$ Tetapi, Indonesia juga memberlakukan hukum adat yang merupakan ciri dari customary law dan mengakui eksistensi Peradilan Agama sebagai ciri muslim law system. Para hakim di Indonesia di dalam praktik mengikuti yurisprudensi yang merupakan ciri common law system. ${ }^{12}$

Hal yang ingin ditekankan dari uraian di atas, adalah bahwa walaupun tradisi hukum di Indonesia berasal dari Eropa Kontinental (civil law system), tetapi tidak mengesampingkan keberadaan yurisprudensi. Putusan Makamah Kontitusi tidak lain merupakan suatu yurisprudensi. Ada beberapa alasan yang mendukung mengapa sebuah Putusan Makamah Konstitusi kemudian dapat dikategorikan sebagai suatu yurisprudensi. Pertama, Purnadi Purbacaraka dalam Soeroso mengemukakan isitilah yurisprudensi berasal dari kata yurisprudentia

\footnotetext{
${ }^{10}$ Otong Rosadi, Andi Desmon, op.cit, h. 44

${ }^{11}$ Jimly Ashiddiqie, op.cit, h. 307

${ }^{12}$ Achmad Ali, 2012, Menguak Teori Hukum dan Teori Peradilan Termasuk Interpretasi Undang-undang, cet. ke-4, Prenada Media Group, Jakarta, h. 499
} 
yang berarti pengetahuan hukum. Adapun dalam bahasa jerman, kata yurisprudensi diartikan ilmu hukum. ${ }^{13}$ Jadi Putusan Makamah Konstitusi sesungguhnya kaya akan akan muatan ilmu hukum, sebagai contoh dalam pertimbangan hukum Makamah Konstitusi yang terdapat dalam Putusan No. 46/PUU-VIII/2010, dimuat pembahasan tentang prinsip negara hukum dan korelasi antara peristiwa hukum dengan akibat hukum. Kedua, yurisprudensi merupakan putusan pengadilan yang telah memiliki hukum tetap dan menurut pendapat Muhtadin Dg. Mustafa, putusan ini dapat pula digunakan oleh hakim yang lain sebagai referensi hukum. $^{14}$ Hal ini bersesuain dengan Putusan Makamah Kontitusi yang bersifat final and binding berdasarkan penjelasan Pasal 10 dalam Undang-undang No. 8 Tahun 2011 tentang Perubahan Atas Undang-undang No. 24 Tahun 2003 tentang Makamah Kontitusi.

Adapun yang menjadi alasan terakhir, bahwa terdapat tiga Putusan Makamah Konstitusi yang pada intinya terkait dengan penafsiran Pasal 33 UUD 1945 tentang Hak Menguasai Negara putusan permohonan judicial review Undang-undang No.20 Tahun 2003 tentang Ketenagalistrikan Nomor 001-021-022/PUU-I/2003, Undang-

\footnotetext{
${ }^{13}$ R. Soeroso, 2011, Pengantar Ilmu Hukum, Cet. 11, Sinar Grafika, Jakarta, h. 159

${ }^{14}$ Muhtadin Dg. Mustafa, 2004, Pemberdayaan Yurisprudensi Sebagai Sumber Hukum Islam (Analisis Fungsional Dalam Rangka Optimalisasi Kinerja Hakim Di Indonesia), Jurnal Hunafa, vol. 1. No. 1, Palu, h. 49-50
}

undang No.22 Tahun 2001 tentang Minyak dan Gas Bumi Nomor 002/PUU-I/2003, dan Putusan Uji materi Undang-undang No.7 Tahun 2004 tentang Sumber Daya Air Nomor 058-059-060-063/PUU-II/2004. Jika dikaitkan kemudian dengan tujuan politik hukum nasional menurut Philippe Nonet dan Philip Selznick, Putusan Makamah Konstitusi sebagai yuriprudensi ternyata memiliki fungsi penting di dalam menciptakan sebuah sistem hukum nasional yang rasional, transparan, demokratis, otonom dan responsif terhadap perkembangan, aspirasi, ekspektasi masyarakat. ${ }^{15}$ Dalam bahasa yang lebih disederhanakan, Putusan Makamah Konstitusi sebagai yurisprudensi merupakan instrument kontrol terhadap segenap produk hukum yang dianggap tidak sesuai lagi dengan kebutuhan masyarakat atau cenderung tertinggal dari suatu peristiwa, bahkan produk hukum yang bersifat inskonstitusional.

Misalnya terhadap keberadaan Pasal 43 ayat (1) Undang-undang tentang Perkawinan yang pada mulanya hanya memberikan hak keperdataan bagi anak luar kawin terbatas pada ibu dan keluarga ibunya saja. Ketentuan pasal ini dianggap inkonstitusional dan tidak sesuai lagi dengan prinsip nondiskriminasi sebagaimana

\footnotetext{
${ }^{15}$ Imam Syakuni, A. Ahsin Thohari, 2013, Dasar-dasar Politik Hukum, cet. 9, PT RajaGrafindo Persada, Jakarta, h. 72
} 
telah diatur di dalam Undang-undang tentang Perlindungan Anak.

Sehubungan sistem hukum di Indonesia bersifat pluralistik (pluralisme hukum), maka hukum yang berlaku tidak hanya terbatas dalam pengertian hukum tertulis yang dibentuk oleh negara (lembaga legislatif bersama presiden). Tetapi di Indonesia juga berlaku hukum adat dan sistem hukum agama. ${ }^{16}$ Berdasarkan Pasal 18 B ayat (2) Undang-undang Dasar Negara Republik Indonesia Tahun 1945, hukum adat diakui sepanjang : (1) masih hidup; (2) sesuai dengan perkembangan masyarakat; (3) sesuai dengan prinsip negara kesatuan Republik Indonesia dan; (4) diatur dalam undang-undang. Dengan demikian, hukum adat haruslah menyesuaikan diri dengan hukum negara, artinya hukum adat yng berlaku tidak boleh bertentangan dengan hukum negara. prinsip ini dalam teori hukum disebut pluralisme hukum lemah. Oleh karenanya juga dirasa perlu untuk melakukan pembinaan terhadap hukum adat yang tidak sesuai dengan perkembangan zaman dengan menghilangkan diskriminasidiskriminasi yang masih terjadi. ${ }^{17}$

Dalam penelitian ini fokus perhatian tertuju pada norma hukum adat Bali yang mengatur bahwa anak astra hanya

\footnotetext{
${ }^{16}$ Beni Ahmad Saebani, H. Encup Supriatna, 2012, Antropologi Hukum, Pustaka Setia, Bandung, h. 333

${ }^{17}$ R. Subekti, 1974, Hukum Adat Indonesia Dalam Yurisprudensi Makamah Agung, Alumni, Bandung, h. 124
}

diperkenankan untuk memiliki hak waris dengan ibunya saja. Secara normatif, hukum adat Bali dapat diartikan telah menghilangkan hak mewaris antara anak astra dengan ayah biologisnya. Berdasarkan 2 (dua) penelitan terdahulu, yakni penelitian tesis Ida Ayu Putu Suryatini ${ }^{18}$ dan tesis karya Ida Made Widyantha ${ }^{19}$ dengan melibatkan kasta dalam perkawinan, maka perlakuan diskriminasi terhadap anak astra akan tetap berlanjut. Sebagai contoh, anak astra tidak dapat disahkan statusnya sebagai anak sah meskipun bapak dan ibunya telah kawin sah. Berikutnya, anak astra dilarang memanggil orang tua biologisnya dengan sebutan bapak dan ibu, namun larangan ini tidak berlaku bagi adiknya yang lahir dalam perkawinan yang sah. Contoh terakhir, perlakuan diskriminasi kembali di alami oleh anak astra dalam tata cara berbahasa jika hendak berbicara dengan adiknya yang lahir dalam perkawinan yang sah, kedua orang tuanya, dan kerabat dari bapaknya dan

\footnotetext{
${ }^{18}$ Ida Ayu Putu Suryatini, 2003, Kedudukan Hukum Anak Astra Setelah Orang Tua Biologisnya Kawin Secara Sah Menurut Hukum Adat Bali" (Studi Kasus Desa Sanur, Kecamatan Denpasar Selatan, Kota Denpasar, Daerah Tingkat I Bali ), (tesis) Program Studi Magister (S2) Ilmu Hukum Universitas Diponegoro, Semarang.

${ }^{19}$ Ida Made Widyantha, 2010, Kedudukan Hukum Anak Astra Dalam Hukum Waris Adat Bali Setelah Orang Tua Biologisnya Kawin Sah" (Studi Kasus Di Lingkungan Monjok Griya, Kelurahan Monjok, Kecamatan Selaparang, Kota MataramNTB), (tesis) Program Studi Magister (S2) Kenotariatann Universitas Diponegoro, Semarang.
} 
dibatasi pula haknya dalam mempergunakan merajan (tempat suci keluarga).

Meskipun hukum adat memperoleh pengakuan dan penghormatan oleh negara secara konstitusional, namun berlakunya hukum adat sebagaimana diatur secara implisit dalam Pasal 18 B ayat (2) Undangundang Dasar Negara Republik Indonesia adalah sangat terbatas. Hal ini sesuai dengan penafsiran atas susbtansi Pasal 18 B ayat (2) sebagaimana dimuat dalam Putusan Makamah Kontitusi NO 31/PUU-V/2007 dan Putusan Makamah Kontitusi No. 6/PUU-VI/2008. Salah satu point penting yang dapat dikutip, yakni substansi norma hukum adat harus sesuai dan tidak bertentangan dengan peraturan perundangundangan. Berdasarkan hal tersebut, maka Indonesia sesungguhnya menganut karakter pluralisme hukum lemah. Hal ini juga dapat diartikan bahwa masyarakat hukum adat tidak lain merupakan bidang sosial semiotonom. Sehingga norma yang dibentuk negara melalui pemerintah atau keputusankeputusan administratif dan pengadilan tetap menimpa bidang sosial semi-otonom yang sebelumnya telah memiliki aturan dan adat kebiasaan sendiri. $^{20}$

20 T.O. Ihromi, 2001, Antropologi Hukum Sebuah Bunga Rampai, cet-2, Yayasan Obor Indonesia, Jakarta, h. 153
Dengan adanya Putusan Makamah Kontitusi No. 46/PUU-VIII/2010 sebagai sebuah yurisprudensi, maka norma hukum adat Bali tentang anak astra harus menyesuaikan diri dengan semangat dari putusan tersebut. Dengan demikian, pasca dikeluarkannya Putusan Makamah Kontitusi No. 46/PUU-VIII/2010, maka hukum adat Bali tentang anak astra yang tidak memberikan hubungan hukum keperdataan antara anak dengan bapak biologisnya secara yuridis tidak berlaku lagi.

\section{SIMPULAN DAN SARAN}

\section{a. Simpulan}

1. Berdasarkan perspektif (tinjauan) Putusan Makamah Konstitusi No. 46/PUU-VIII/2010, anak astra mempunyai hubungan perdata dengan ayah biologisnya beserta keluarganya sepanjang dapat dibuktikan berdasarkan ilmu pengetahuan dan teknologi dan/atau alat bukti lain menurut hukum.

2. Konsekuensi yuridis Putusan Makamah Kontitusi No. 46/PUU-VIII/2010 terhadap hukum adat Bali tentang kedudukan anak astra adalah bahwa hukum adat Bali harus menyesuaikan diri dengan arah hukum dalam Putusan Makamah Konstitusi.

\section{b. Saran}

1. Kepada Desa Pakraman diharapkan merivisi awig-awig tentang kedudukan 
anak luar kawin dengan menyesuaikan pada Putusan Makamah konstitusi No. 46/PUU-VIII/2010. Terlepas dari urusan sah atau tidaknya perkawinan kedua orang tua si anak, namun setiap anak yang lahir harus dilindungi dan diberikan kepastian hukum mengenai statusnya sebagai anak dan hak-hak yang melakat padanya.

2. Kepada Parisadha Hindu Dharma dan Majelis Utama Desa Pakraman di Bali hendaknya melakukan penafsiran hukum adat Bali tentang kedudukan anak astra dengan harapan agar hukum adat yang dimaksud lebih sesuai dengan perkembangan masyarakat.

\section{DAFTAR PUSTAKA}

Ali, Achmad, 2012, Menguak Teori Hukum dan Teori Peradilan Termasuk Interpretasi Undang-undang, cet. ke4, Prenada Media Group, Jakarta

BPHN, 1976, Seminar Pembinaan Hukum Adat dan Pembinaan Hukum Nasional, Binacipta

Ihromi, T.O., 2001, Antropologi Hukum Sebuah Bunga Rampai, cet-2, Yayasan Obor Indonesia, Jakarta

Jimly Ashiddiqie, 2010, Konstitusi dan Konstitusionlisme Indonesia, Sinar Grafika, Jakarta

Mustafa, Muhtadin Dg., 2004, Pemberdayaan Yurisprudensi Sebagai Sumber Hukum Islam (Analisis Fungsional Dalam Rangka Optimalisasi Kinerja Hakim Di
Indonesia), Jurnal Hunafa, vol. 1. No. 1, Palu

Otong Rosadi, Andi Desmon, 2012, Studi Politik Hukum Suatu Optik Ilmu Hukum, Thafa Media,Yogyakarta

Saebani, Beni Ahmad, H. Encup Supriatna, 2012, Antropologi Hukum, Pustaka Setia, Bandung

Soeroso, R., 2011, Pengantar Ilmu Hukum, Cet. 11, Sinar Grafika, Jakarta

Subekti, R., 1974, Hukum Adat Indonesia Dalam Yurisprudensi Makamah Agung, Alumni, Bandung

Sukerti, Nyoman, 2012, Hak Mewaris Perempuan Dalam Hukum Adat Bali Sebuah Studi Kritis, Udayana University Press, Denpasar

Suryatini, Ida Ayu Putu, 2003, "Kedudukan Hukum Anak Astra Setelah Orang Tua Biologisnya Kawin Secara Sah Menurut Hukum Adat Bali (Studi Kasus Desa Sanur, Kecamatan Denpasar, Kota Denpasar Daerah Tingkat 1 Bali) “ Diponegoro, Semarang

Syaukani, Imam, Thohari, A. Ahsin 2013, Dasar-dasar Politik Hukum, cet. 9, PT RajaGrafindo Persada, Jakarta

Widyantha. Ida Made, "Kedudukan Hukum Anak Astra Setelah Orang Tua Biologisnya Kawin Secara Sah Menurut Hukum Adat Bali (Studi Kasus di Lingkungan Monjok Griya, Kelurahan Monjok, Kecamatan Selaparang, Kota Mataram-NTB)", Tesis Universitas Diponegoro, Semarang

Witanto, D.Y, 2012, Hukum Keluarga Hak dan Kedudukan Anak Luar Kawin Pasca Keluarnya Putusan MK Tentang Uji Materiil UU 
Perkawinan, Prestasi Pustaka

UU Nasional, CV. Mandar Maju, Publisher, Jakarta

Bandung

Yusuf Hanfi, 2011, Kontroversi Perkawinan Anak di Bawah Umur Perspektif Fikih Islam, HAM Internasional, dan 
